\title{
HOUSE ARREST AS A PREVENTIVE MEASURE IN ACCORDANCE WITH THE NEW CRIMINAL PROCEDURE CODE
}

\author{
Silviu JÎRLĂIANU \\ “Dunărea de Jos" University, Galaţi, Romania \\ jirlaianu@yahoo.com
}

\begin{abstract}
Romania's participation in European Community imposed realities of our country harmonization of national legislation in relation to Community law. Such national legislation, in terms of criminal procedure were introduced through preventive measures, house arrest, judicial and Judicial control on bail. In relation to the same European context, Romanian police set up surveillance units of judicial duties in order to enforce these measures.
\end{abstract}

Keywords: judicial control, judicial control on bail, house arrest, judicial supervision structures.

\section{Introduction:}

In the context of the New Criminal Procedure Code, the judicial control, the judicial control on bail and the house arrest are preventive measures involving deprivation of liberty which may be ordered if there are any consistent evidences or clues to support reasonable doubt that an individual has committed a crime and if they are necessary to ensure the proper conduct of the criminal proceedings, to prevent the suspect or the defendant from avoiding prosecution or trial or to prevent the commission of another offense.

\section{Legal categorisation and sanctions.}

According to article 202 [1] in the Criminal Procedure Code the preventive measures include:
a) detention.
b) judicial control.
c) judicial control on bail.
d) house arrest.
e) pre-trial detention.

Any preventive measure should be proportionate to the gravity of the allegations made against that person and should be necessary in order to achieve the aim pursued by its ordering.

The preventive measures indicated in articles b), c) and d) are measures which do not involve deprivation of liberty and which are ordered with the purpose of ensuring the proper conduct of the criminal proceedings, of preventing the suspect or the defendant from avoiding prosecution or trial or of preventing the commission of another offense.

Preventive measures involving judicial control and judicial control on bail may be taken against the defendant by the prosecutor and the justice of peace, during prosecution, as part of the preliminary chamber procedure and by the court, during trial. They are ordered by the prosecutor through reasoned order, and by the court through reasoned ruling.

The preventive measure involving house arrest may be taken against the 
defendant by the justice of peace during prosecution, as part of the preliminary chamber procedure, and by the court during trial.

According to the law, the responsibility to monitor individuals against whom authorities have ordered measures like judicial control, judicial control on bail and house arrest, lies with the Romanian police through its legal monitoring structures.

The activity is carried out in accordance with Decision no. 9/ 02.10.2014 of the General Inspectorate of Romanian Police on the organization of specific activities carried out by the Romanian police with the purpose of monitoring individuals against whom authorities have ordered measures like judicial control, judicial control on bail and house arrest.

At a national level, the monitoring activities of individuals against whom authorities have ordered preventive interdiction measures are coordinated by the Criminal Investigation Directorate within the General Inspectorate of Romanian Police.

At a territorial level, this activity is coordinated by the Criminal Investigations Department and lies within the responsibility of the deputy chief inspector who coordinates the criminal investigation activities.

The municipal police units (except for county capital cities) and the city police units include departments which subordinate to the chief of the criminal investigation departments.

At the level of the Bucharest General Directorate of Police the activity is coordinated by the Criminal Investigations Service, and the criminal investigation offices within the police stations include specialized departments.

The police unit (from the municipality or the city) in the area where the defendant lives or the police unit determined by the court through ruling or by the prosecutor through ordering, has territorial jurisdiction for monitoring the individuals against whom authorities have ordered measures like house arrest, judicial control, judicial control on bail.

In case of county capital cities and the assigned communes, the monitoring of these individuals is carried out by a specialized department within the Criminal Investigations Service.

Individuals living in the country side shall be monitored by the law enforcement body (from the municipality or the city) within the assigned police station, in the area where the defendant lives.

If the prosecutor / court orders that the defendant is not to leave a certain designated area, and if, as a result, the defendant cannot go to the headquarters of the designated monitoring department, the activities related to his appearance before the supervisory body shall be carried out by the police station in the area where the defendant is domiciled; the police officer assigned to perform the monitoring activity shall be also responsible for the other monitoring activities.

At the level of the General Directorate of Bucharest Police the supervisory power is entrusted to the police station in the area where the defendant is domiciled.

Romanian Police departments constituted for monitoring individuals against whom authorities have ordered some interdiction measures shall carry out specific activities related to:

a) the monitoring of individuals against whom authorities have ordered measures like house arrest, judicial control, judicial control on bail;

b) the investigation of criminal files related to offenses committed and associated with the monitored individuals;

c) the tracking of these individuals in case the court decides to change the measure with pre-trial detention, and the defendant absconds.

d) the gathering of information related to those individuals; 
e) the managing of the records of individuals released from prison;

f) information supplied by citizens regarding the monitored individuals.

The Criminal Investigation Directorate may take on, with the agreement of the judicial body who ordered the preventive measure, the monitoring activity of the individuals investigated within the directorate or investigated in files drawn up by the Public Prosecutor's Office attached to the High Court of Cassation and Justice, and whose domicile is in the area of municipality of Bucharest or Ilfov county.

The Criminal Investigation Service within the General Directorate of Bucharest Police or the County Police Inspectorate may take on, with the agreement of the judicial body who ordered the preventive measure, the monitoring of individuals who were investigated within the directorate or who have committed serious crimes or have used special operating modes.

\section{Incrimination.}

The house arrest measure, according to article 218 [2] and ensuing articles from the New Criminal Procedure Code, consists in the obligation imposed on the defendant, on a determined period of time, not to leave the premises of his house without the permission of the judicial body who ordered the measure or who is investigating the cause, and to obey certain restrictions determined by them.

The defendant's obligations during house arrest are as follows:

- to appear before the prosecution authorities, the justice of peace, the preliminary chamber judge or the court, each time he is called for;

- to avoid any communication with the injured party or his/her family members, with other participants in the crime, with witnesses or experts, as well as other individuals as determined by the judicial body.
The justice of the peace, the preliminary chamber judge or the court may order the defendant to permanently wear an electronic monitoring system, during house arrest.

The decision expressively lays down the obligations the defendant must comply with, and warnings that in case of malicious violation of the measure or his obligations, house arrest can be replaced by pre-trial detention.

Upon the defendant's written and motivated request, the justice of peace, the preliminary chamber judge or the court, by their decision, may allow the defendant to leave the premises of his house in order to go to work, to attend teaching classes or undergo professional training, or for any other similar activities, to procure essential means of subsistence, as well as in other duly justified cases, for a determined period of time, if this is necessary for the observance of the rights or legitimate interests of the defendant.

During this measure, the defendant may leave the premises of the house in order to appear before the judicial bodies, as instructed by them.

In emergency cases and for very good reasons, the defendant may leave the premises of the house for the required period of time without the permission of the justice of peace, of the preliminary chamber judge or the court, provided that he immediately informs the institution, the body or the authority responsible for monitoring him and the judicial body who ordered the house arrest or who is investigating the cause.

Emergency case means saving his or another person's life, bodily integrity or health from immediate danger, or his or another person's important goods or general interest. The monitoring body shall check the reality and the validity of the reasons invoked by the defendant.

Police officers assigned to conduct monitoring activities will immediately go to the defendant's home, prove his identity and the identity of the persons usually 
living with him and his dependents, and make a report in this respect, after which communicate to the judicial body who ordered the measure, that they proceeded to the monitoring activities.

The monitoring body shall draw up a program which includes the implementation way of the house arrest measure, the obligation to provide information when leaving the house for emergency cases and, where appropriate, the conditions for leaving, movement and returning. This program shall be brought to the defendant's knowledge, under signature.

In case the judicial body accepts the defendant's application to leave his house with the purpose of going to his job, of attending teaching classes or undergoing professional training, or for any other similar activities, or with the purpose of procuring essential means of subsistence, as well as in other duly justified cases, for a determined period of time, or convenes him, by showing the convening date, time and place, the police officer responsible with his monitoring shall set up two itineraries (a main one and a back up one), the conditions for movement as well as the timeline for the itinerary. In case the decision of the judge specifically sets up the movement itinerary and the related timelines, these provisions shall be mandatorily included in the monitoring program, without alternative arrangements.

Should the defendant be forced to use the backup itinerary, or a different one which was not included into the monitoring program, from reasons outside his control, the defendant shall immediately contact the monitoring body, who will provide him with movement instructions related to that itinerary and that timeline.

The monitoring body shall keep the judge who ordered the measure regularly informed on its implementation way.

In case the defendant who is allowed by the decision to leave the house, changes the location where he actually performs his activity, the monitoring body, following verifications (and through the conclusion of a verification report) shall inform the judge about the amendment.

The file of the individual on house arrest may be seen by the defendant or, only by his written agreement, by his defense lawyer or any other person, who also have the right to make copies of the documents in the file.

The judicial bodies may also see the defendant's individual file.

The police officer responsible with the monitoring shall carry out at least 3 random checks at the defendant's house, at different hours. In accordance with article 221 [3], paragraph 10 from the Criminal Procedure Code, the police officer also has the right to enter the defendant's house without his approval or the approval of the persons living with the defendant.

If, following the random checks and the verifications, the monitoring body finds that the defendant has maliciously failed to comply with the measure and/or his obligations, he will draw up a reasoned notification for the judicial body who ordered the measure.

In order for him to draw up the reasoned notification, the monitoring body may proceed with the hearing of the defendant or other persons.

The duration of this preventive measure is indicated in article 222 [4] from the Criminal Procedure Code. During prosecution, the house arrest is maximum 30 days, with the possibility to be extended for another 30 days in case the grounds which led to the measure being taken are to be maintained or in case of new grounds.

The maximum duration of house arrest, during prosecution, is 180 days.

\section{Conclusions:}

The house arrest measure, although highly preventive, is a measure which involves deprivation of liberty but equally permissive for the arrested defendant, whose only obligation is not to leave his place of residence. 
The defendant is also obliged to follow a few other specific restrictions, but in fact, his freedom of movement is enhanced, having unlimited access to audio-video means of communication, the right to receive visits from relatives and friends, without any restriction, and access to other recreational activities, as far as the limit of his domicile and its surrounding allows it.

We thus believe that, as this is a preventive measure, it is however necessary to restrict the defendant's freedoms.

[1] New Criminal Procedure Cod, art. 202.

\section{References}

[2] Ibidem, art. 218

[3] Ibidem, art.222

[4] Ibidem, art.221 